Historic, Archive Document

Do not assume content reflects current scientific knowledge, policies, or practices. 




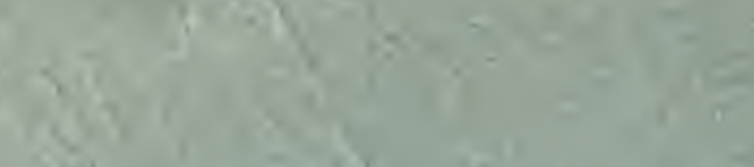
$6 y_{2} y^{1}=28$ $+3, x+1, y$

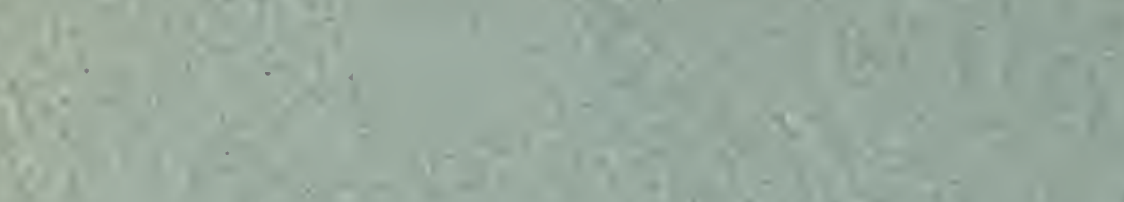

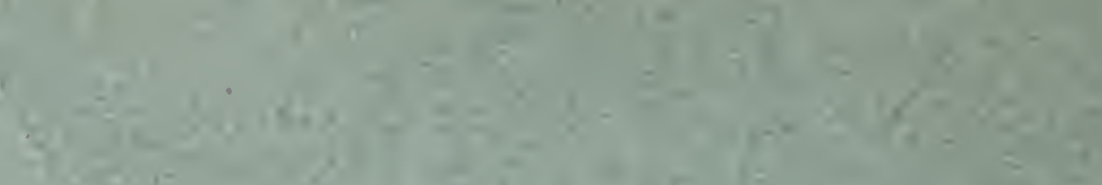

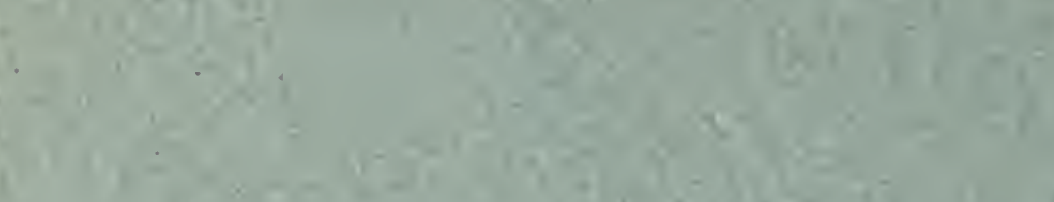

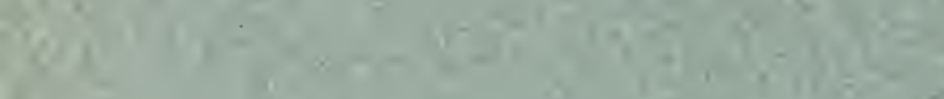

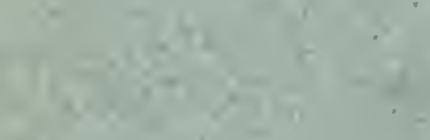

B.

ing

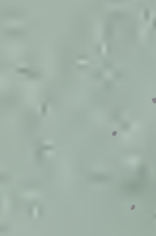

$x^{2}$

tat

(nix) 50 (2) 5in: 5

$10^{2} x^{2}-48$ $\therefore=-1 / 9,28$ $=4 x^{2}+2$
28 


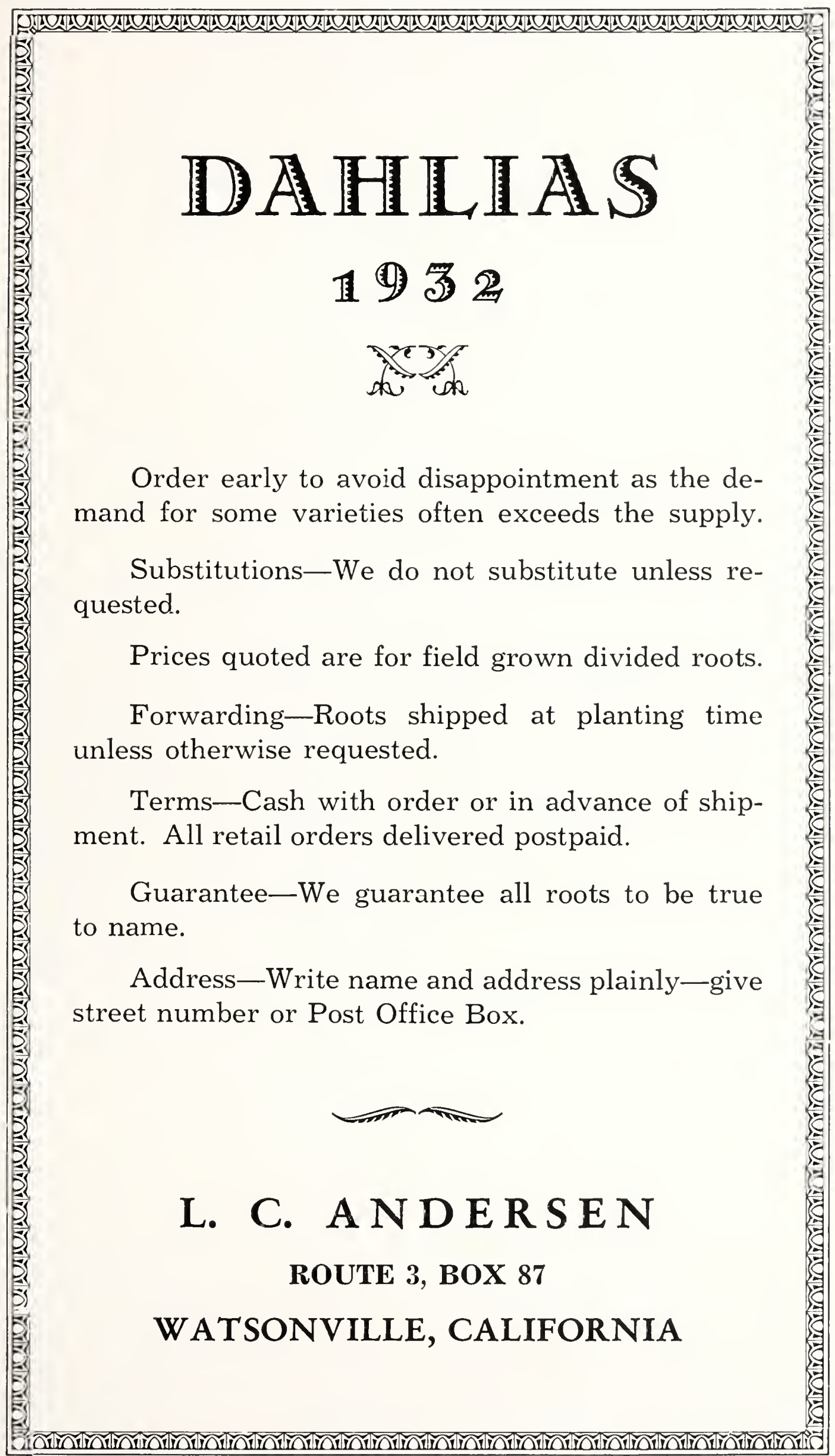

TRADE DISCOUNTS $1 / 3$ OFF 


\section{Culture of Dahlias}

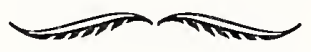

Dahlias are growing more and more popular each year, for several reasons. They bloom here from early June until they are cut down, in full bloom, in November.

They are easily raised. They will grow in any soil and will give good results if a little care is given them.

The different varieties of Dahlias resemble so many other flowers; for example, one woman in the garden four years ago insisted that Cactus Dahlias were chrysanthemums. Some are like peonies, roses.

As to the soil-it is very essential that the soil have good drainage. The poorer the soil the more fertilizer is required; the lighter the soil, the more water it needs. As a rule, nothing will grow without nourishment. Dahlias, like children, need food, drink and training in the right way.

If your soil is heavy with clay subsoil it should be lightened with coal or wood ashes or sand. One part of coal ashes or sand and one part soil will not lighten it too much.

We hear so much that, "Our soil is adobe and we cannot raise Dahlias in it." Another man said, "I have adobe soil, but I add wood ashes and have some fine Dahlias."

Let anyone visit the Dahlia Show, held each September at the Palace Hotel in San Francisco, and see the Dahlias. The greater part of them were raised in adobe soil.

Soil should be prepared thoroughly by digging 12 to 18 inches deep, in the fall, if possible, and again in the spring.

Planting time differs. In warmer climates, as in the southern part of the state, and in the hot valleys, as the San Joaquin and Sacramento valleys, the time for planting is in March, if the weather is pleasant. By the time the plant is up all danger of frost is over. Then you have your bloom before the exceedingly hot season comes. When the sun shines so hot it burns your flowers and foliage, cut your plant off at the ground, water, and let it grow up and bloom again until frost comes.

Where there are heavy frosts until up in April or May, it is not best to plant until all danger of frost is over. But I would advise sprouting your bulbs; then you can have earlier blooms.

To Eastern customers. We ship as soon as it is safe to send them without freezing. When you receive them it will be time to plant. If possible, plant in an open, sunny situation.

Referring to the description in this list, there ought to be made certain allowances for variations, caused by different soils and climatic conditions. These are classed as they have grown with us. In warmer climates many that are peony flowering with us, come as decorative. 
Prepare the soil by a second good spading in the spring. Dig holes about 16 inches deep and three or four feet apart. Fill up the holes with earth and a shovel of fertilizer, mixing together, to within eight inches of the top (always plain soil on top in which to plant your root).

Plant your root in a slanting position, with the crown containing the eye or sprout (i. e., the small end of the root). Cover with loose, mellow soil to a depth of four inches. The hole can be filled up as the plant grows.

Keep the ground well cultivated and free from weeds. A more frequent stirring of the surface is beneficial. Never leave more than three stalks to a plant. One is preferable, as you then have better plants and larger flowers. Any kind of fertilizer occasionally used during the flowering season will make better and larger flowers.

To water. We make a trench around each plant and give each stalk all it will drink. So many failures in growing Dahlias are on account of lack of water. The stalk of a Dahlia is about all water except the outside shell. Sufficient water is needed to keep the stalk supplied. Large flowers require water, fertilizer and disbudding.

The question is asked over and over: "How do you keep your plants so low? Mine grow 12 to 15 feet high." This is the question of all from the hot sections of the state. In reply, I would say that unless the season is unusually dry do not water your plants until the buds begin to form. The object is to keep the plant growing, but as strong and sturdy as possible. Just as soon as the plants are up, the most important thing to do is to keep the soil loose and mellow by hoeing or cultivating once or twice a week and, just as soon as the buds appear, stop all cultivation, clipping, etc., and around the base of each plant place a shovel full of well-rotted manure if possible. Water the beds thoroughly once or twice a week, and especially during dry weather.

Some ask: "What is it to disbud?" As the bud forms you will find two or three buds on the top of your main stalk, and on each side of your stalk little branches coming out, so many inches apart all the way down. To disbud, pick off all but the largest bud on top, then pinch off the little branches that are coming out on your stalk at least 12 inches from your top bud. Each stalk or branch is disbudded in the same manner. Pa Fenton says: "If you want large flowers, you must disbud. If you want good flowers, you must disbud. If you want flowers that will keep, you must disbud. If you want to keep your Dahlias low, you must disbud. If you do not disbud do not raise Dahlias."

Never allow faded flowers to remain on the plant, but cut them off with as much stalk as you can. Dahlias will bloom until the frost kills the top, after which cut off the tops. Tops should be cut off in November, where you do not have frosts. Roots should be stored in a frost-proof cellar or basement, covering with dry soil or sand to keep from shriveling. Divide in spring, after eyes begin to show.

Important-When you receive your roots, put them in a cool place or in a box of soil and keep moist until ready to plant. Do not allow them to dry out. 


\section{Decorative Dahlias}

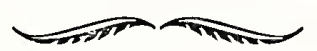

Aibonita_Lavender or violet pink, shading to white, with good stems. $75 \mathrm{c}$.

Al Koran-Yellow suffused with gold and amber. The petals are wavy and make the flower quite attractive. Long, stiff stem. $75 \mathrm{c}$.

Alex Waldie-Immense flowers, held erect on strong stems; coloring is a creamy ground overlaid with delicate salmonpink. 75c.

Alcalde-Rich old rose and bronzy pink tones. On rare occasions this plant will throw a few blossoms which are beautifully marked paper white. $\$ 2.00$.

Amelia Anna Kearney-Very large with long and strong stem. The color is watermelon color. $75 \mathrm{c}$.

Amun Ra-Very large decorative of deep rich shades of copper and orange shading to gold and amber, held high on a long stiff stem. $50 \mathrm{c}$.

Anna Maier-Pinkish red like old velvet, varying to a soft yellow red toward the center. The stems are long and wiry. $75 \mathrm{c}$.

Bagdad-Flaming Scarlet red. A wonderful flower of immense size and great depth. The long stems hold the large blooms high above the tall growing bush. $\$ 7.50$.

California Sunshine-Brightest light flame, with a gold suffusion. The very best Dahlia we know, in these colorings. It is a good, strong grower, with exceptionally desirable stems. We recommend this variety very highly to those who want the best. Root, each $\$ 2.00$.

C. C. Moore-A flower admired by all who see it. It is hard to tell whether it is a decorative or a full peony. It is a beauty of lovely orange shade, a good size stem, and is good as a cut flower. 50c.

Clarissa Blanco-The color is deep claret wine, sometimes marked white. This variety may be depended upon to always make a wonderful showing, anywhere. In the garden it blooms in great profusion. $\$ 1.00$.

Champagne-A gorgeous bloom of enormous size, held high on long stiff stems. The color is a soft blending of dull golden champagne varying to chamois. $75 \mathrm{c}$. 


\section{DECORATIVE DAHLIAS-Continued}

City of Los Angeles-One of our new Dahlias. Beautiful salmon-colored hue, blending into a flush pink and autumn tinted color so much in demand; admired by all who see it, with large flowers and perfectly formed long stout stems. Root, each $\$ 3.00$.

Dr. H. L. Tevis-This is one of the best known California Dahlias, it having won many awards wherever shown. The bloom is very large, and always upon a good strong stem. The colorings are best described as being of the lighter apricot shades. Root, each 50c.

Earl Williams-Giant flowering Dahlia. Color, a brilliant crimson and white, well distributed. Free bloomer; one of the finest and most attractive Dahlias ever introduced. $\$ 1.00$.

Elinor Vanderveer-A beautiful Dahlia and one which has been greatly admired in our garden. Large full flower of a rose pink on extra long stiff stems. An early bloomer. 75c.

Faith Garibaldi-Decorative. Deep rose pink. A bloom of great substance and perfect formation on strong stems held high above the foliage. A good keeper as a cut flower and a prize winner in many shows. $\$ 1.00$.

Flaming Meteor-A flaming red, best described as an orange scarlet, deepening to burnt orange in the center, with petals showing an amber yellow base. Good form, and a real florist variety. Root, $\$ 1.00$.

Golden Oriole-Very early and free blooming. Golden yellow, slightly suffused bronze. A splendid exhibition variety. We grow it eight to ten inches in diameter. Root, each 50c.

Heart's Desire-Exquisite light salmon rose color. Large, perfect in form and has very good stem. $75 \mathrm{c}$.

J. W. Davies-The coloring of this beautiful Dahlia is difficult to describe; the deepest shade of cerise at the center, graduating to a lighter tint. This blending of the two shades creates an entirely new effect. The immense flower has depth as well as size and the stem is perfect, making it as good for cutting as exhibition. It blooms profusely all the season. One of the most admired Dahlias in our garden. \$1.00.

Jane Cowl, (Downs) - The best Dahlia introduction in several years, and the bloom which caused the sensation of the New York Show, 1927, when Miss Jane Cowl chose it, as a seedling, to bear her name. This deep, massive bloom is a glisten- 


\section{DECORATIVE DAHLIAS-Continued}

ing bronzy buff and old gold, shading deeper toward the center, reverse of petals a pale flesh color. Described as a Dahlia which is "alive." The foliage is the thick, leathery kind that insects do not bother. There is no introduction in many years which has had the prospect of a brilliant future such as "Jane Cowl" undoubtedly has. \$2.50.

Jessie K. Prescott, D.-The color is a deep orange at the center, gradually shading to a creamy orange on the outer row of petals. The formation is unusual as the long, narrow petals have an inclination to roll backwards. Tall bushes, giving a quantity of blooms with good stems. We recommend it highly. $75 \mathrm{c}$.

Jersey's Beauty-One of the outstanding Dahlias which has won favor the world over. Clear pink in color. The large and perfect flowers are freely produced on ideal stems and keep wonderfully well when cut. $\$ 1.00$.

Junior-An enormous flower of pure lavendar, the centers remaining closed throughout the entire season. This huge blossom is a seedling of the Millionaire, but has greater width. Junior is truly wonderful in the garden and as a flower to be used in competition in the largest Dahlia class, having won several first prizes in different parts of the country. $\$ 1.00$.

Kemp's Violet Wonder. Formal Decorative. (Kemp)—Bright royal purple, an unique shade and absolutely new. An impressive flower very large and deep on fine stems. One of the best new Eastern varieties. Root $\$ 4.00$.

King Tut, D.-An extra large blossom of rich, dark, velvety crimson burgundy. Fine formation and a good stem. Was frequently ordered in our trial garden last season. Has been a prizewinner for Mrs. Seal during the last two seasons. Root 75c.

Kittie Dunlap-Large flowers on long, firm stems. Color is a delightful shade of American Beauty rose. Good for cutting. $75 \mathrm{c}$.

Le Grande Manitou-One of the older Dahlias, which is always in good demand. Variegated, purple and white. Large and very attractive. Root, each 50c.

L. C. Andersen-Blossoms are of good size, borne on strong upright stems. The color is a very rich shade of golden apricot. One of the best. Root, each $\$ 1.00$. 


\section{DECORATIVE DAHLIAS-Continued}

Little Jewel (Jeweltje Miniature Decorative)-Sometimes described as a Pom, but really a distinct type. A charming little pink bloom which has come to be one of the best sellers in cut flowers in the leading markets. A free bloomer on long, stiff stems. The perfect center and the exceptional form of the bloom make it one of the best varieties to grow for cutting. No garden should be without it. 50c.

Logan's White-Snow white. The blooms are large and perfect on long, rigid stems. $75 \mathrm{c}$.

Lady Celia-One of our new Dahlias. It is a pure bright cerise rose; large flowers on long, wiry stems. Root, each $\$ 1.00$.

Marjorie Cook-A flower admired by all who see it. Old rose, buff and yellow. Although not of large size, it attracts immediate attention due to its beautiful color, low growing bushes and good stems. $\$ 1.00$.

Mary A. Burnett (1928) - One of the finest white decoratives produced in years. The flowers are very large and have great depth and fine substance and excellent stems. The flowers do not burn in the hottest sun; this Dahlia does very well in this locality. $\$ 4.00$.

Meadow Lark-A very graceful flower of old rose, buff and yellow. Held high on long, straight stems. $75 \mathrm{c}$.

Mrs. Alfred B. Seal-An immense flower of glowing old rose, one of the most beautiful shades in a Dahlia. This Dahlia won the Achievement Medal for the best new Dahlia west of the Rocky Mountains. \$7.50.

Mrs. Eleanor Martin-With a color all its own. Mulberry suffused with gold, and one of the best ever originated. One of the finest in the garden. $\$ 1.00$.

Mr. Crowley-The color of this Dahlia is most beautiful. A glowing salmon pink, the base of the petals a soft yellow. Although not of large size, it attracts immediate attention due to its wonderful coloring. $75 \mathrm{c}$.

Miss California-Perfectly formed and beautiful in color, known as Oriental fuchsia. $\$ 1.00$.

Miss San Francisco-True orchid shade mixed with a deep rose. Flowers are held high above the foliage on a very strong stem. $\$ 2.00$. 


\section{DECORATIVE DAHLIAS-Continued}

M. H. DeYoung-An extremely good flower. Pure old gold in color. Always a mass of immense blossoms, which are borne high on stiff stems. $\$ 2.00$.

Mrs. Minnie Hall-One of our best 1930 introductions. The color is flaming scarlet. A Dahlia with a splendid habit of growth, the bush being of medium height with the flower stems growing right out of the foliage, perfectly straight and stout. An excellent new variety. $\$ 7.50$.

Mrs. Carl Salback-An excellent large decorative of a beautiful shade of pink, shading lighter to the center. The immense blooms are held erect on extra long, strong stems. A perfect cut flower and exhibition variety. 50c.

Mrs. I. De Ver Warner-Large flowers of a rich mauve pink. Long, stiff stems, prolific bloomer and a good cut flower. 75c.

Myrtle Thorne-The blossom is large and of a new shade described as Fuchsia. Excellent stem and good keeping qualities. $75 \mathrm{c}$.

Mrs. A. S. Musante-This is a large and attractive Dahlia. Color is a mauve suffused with a delicate rose pink. The flowers are full and have great depth, which give them the formation of a huge ball. A fine exhibition variety. $\$ 3.00$.

Mother Machree-Cream or ivory white with a touch of pink at the center. Color is out of the ordinary and the large flowers on tall stalks are outstanding in the garden. $\$ 4.00$.

Nobilis-A charming decorative of large size. A blending of brilliant crimson and white. One of the most attractive flowers in the garden. $\$ 1.00$.

Orientale-Formal Decorative-(Newsom-1931) Occasionally, perhaps, over your radio, or at the concert you will hear the enchanting strains of Cui's "Orientale," bringing before you visions of all the luxuries of the East. The Dahlia, Orientale, expresses these same feelings in color, with its rich, warm voluptuous, oriental tones of deep glowing orange, and hints of amber at the tips of the petals. Borne proudly on the ends of long rigid stems, these large, showy blooms can be seen all over the garden, and fairly gleam with subdued light as the sun strikes them. The bushes are very tall and vigorous, with rich dark green foliage. Orientale will delight you. Price per strong, field grown, divided root $\$ 10.00$. 


\section{DECORATIVE DAHLIAS-Continued}

Peerless-An exceptionally fine, clear sulphur yellow flower. $75 \mathrm{c}$.

Pride of California-Large, deep red flowers of fine form and good keeping qualities. Held high on long, rigid stems. 50c.

Princess Pat-A most beautiful flower of old rose, deepening toward center. Flowers large and perfectly formed on long, stout stems. $75 \mathrm{c}$.

Queen of the Garden Beautiful-A flower that fulfills the dream of Dahlia lovers. One of the largest of all Dahlias, measuring from nine to twelve inches across, and five to six inches deep. Grown without forcing. The stems are unusually strong and it is a wonderful keeper. A gigantic, lemon-colored decorative type of bloom. Roots, each $\$ 1.00$.

Rory O'More-A striking fancy of deep maroon, tipped white. Large flowers and perfect stems. A very attractive variety, especialiy in the garden. $75 \mathrm{c}$.

Rose Nell-Color a clear bright rose, which attracts immediate attention. The flowers are immense and of perfect form on extra long, wiry stems. Does well in a warm climate. $75 \mathrm{c}$.

Rookwood-The color is pure bright cerise rose without a touch of magenta. The flowers are large, deep, and on strong stems. $\$ 1.00$.

Santa Barbara-Formal Decorative-(1930 introduction of Frank D. Pelicano \& Son). The color is an intense clear pink, with a suggestion of a suffusion of salmon pink. The big flowers are held high above the foliage on stems stiff as canes, and look one squarely in the face. The medium tall bushes are very strong and hardy. Santa Barbara won the Achievement Medal for the best Dahlia introduced for the season of 1929-30. Root $\$ 7.50$.

Santuzza-A beautiful Dahlia with a color everyone admires, a beautiful soft coral pink. The flowers are large and well formed, with good depth, and held erect by strong stems. This Dahlia is a fine producer of blooms, and as an exhibition variety it is unequalled. $\$ 2.50$.

Senorita-An unusually large and showy flower. A rich velvety crimson blossom that is held erect on a long, stiff stem. Price per root, $\$ 1.00$. 


\section{DECORATIVE DAHLIAS-Continued}

Shudow's Lavendar-1921 introduction of great merit. Large, splendid bloom of silvery lavender, slightly shading to white. Held on long, stiff stems, well above its attractive lace-like foliage. A great prize-winner. $\$ 1.00$.

Sinbad of the Sea-Formal Decorative-(Newsom-1931) One of the most popular of all. A huge, perfectly formed flower of vivid scarlet, a trifle darker than Tommy Atkins, and very much larger and more beautiful. A free bloomer that needs very little disbudding. The medium tall bushes are always covered with large, perfect blooms on absolutely cane-like, stiff stems. The flowers look you right in the face, and last for days when cut. Sinbad of the Sea is going to prove a most valuable addition to any collection. Price per strong, field grown, divided root $\$ 10.00$.

Siskiyou-Pink-tinted mauve. This produced the largest flowers we have ever grown. It has created a sensation wherever shown and attracted more attention than any other flower in our gardens the past summer. The plants are extra sturdy and vigorous, and the flowers are held perfectly erect on strong stems. $\$ 1.00$.

Susan G. Tevis-This decorative has a distinctly new color tone, best described as a deep shade of lilac with a bluish sheen. The blossoms are held upright on long, stout stems. An excellent exhibition and cut flower. \$1.00.

Tryphinnie-Bright shell pink with golden suffusion and yellow at base of petals. $75 \mathrm{c}$.

Waldheim Sunshine-This giant yet graceful Dahlia is one of the best. A true deep yellow that will show up yellow under artificial light. The reflex is darker, and there is a rich golden suffusion around the beautiful full, high centre. The bush growth is good, stems are strong and erect. It is a sturdy grower and free bloomer. The centres were perfectly full when killed by frost. $\$ 4.00$.

Wizard of $\mathrm{Oz}-\mathrm{An}$ immense Dahlia of a rare shade of a glowing amber pink. Blossoms held on strong, stiff stems. $\$ 1.00$.

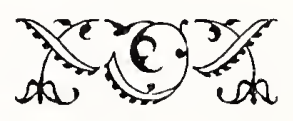




\section{Cactus and Hybrid Cactus Dahlias}

Ambassador Cactus-Giant flowering, and one of the outstanding of California Dahlias. The colorings are of the softer tones of yellow, buff, and salmon pink. The petals are straight and pointed at the tips. Fine formation, good stems, and good keeping qualities. This Dahlia has the reputation of having been sold at fifty dollars when first introduced. Exhibit this one. Roots, each $\$ 1.00$.

Ballet Girl-The greater percentage of flowers are orange, with white edge. Others are pure orange, and some white, edged orange. All large and beautiful. $75 \mathrm{c}$.

Bear Claws-A tall growing plant bearing numerous large carmine blooms with petals long and incurved in such a manner that the name is exceptionally fitting. Unusual. Root 75c.

California Enchantress-An enormous bloom of pale pink, on long, stiff stem. Splendid cut flower. 75c.

Cherry-A rich crimson shaded maroon, full centered on strong stems and a prolific bloomer and fine keeper. One of the best. $75 \mathrm{c}$.

El Granada-Color is a vivid orange with petals which twist and interlace, showing a creamy yellow reverse at the tips. Consistent prize winner. A wonderful Dahlia. \$1.00.

Fluffy Ruffles-This novelty is a new combination of color. Beautiful blossoms of golden fawn, with a satin sheen, shading to a golden yellow at center. The petals twist and turn, showing old rose tones on the reverse side. Flowers are held erect on good stems. $75 \mathrm{c}$.

Francesca-An enormous Hybrid Cactus. We shall call it a dull, tanned rose, with a distinct violet suffusion. There are old gold markings on the petals, and a distinct bluish sheen. Under artificial light you can pick out almost every color imaginable. It has a perfect stem of great strength, holding the flower well above the foliage, and is a prolific bloomer, with attractive foliage and good growing habits. \$2.00.

Gladys Sherwood-The largest white hybrid cactus. Deep and full to the center, with good stems. Highly recommended for garden exhibition. 75c.

Gertrude Ederle-Primrose yellow. Large flower, profuse bloomer, with long strong stems. $\$ 2.00$. 


\section{HYBRID CACTUS DAHLIAS-Continued}

George Walters, H. C.-Pinkish salmon suffused with gold; one of the largest and best. 75c.

Hong Kong (Peony-Cactus) - This flower is inclined to resemble the peony type more than it does the cactus type; nevertheless, it often has rather sharp-pointed petals and is perhaps about one-fourth cactus type. Oriental colors, of buttercup yellow toward the center, while the outer petals are shaded a deep tomato red. $75 \mathrm{c}$.

Inkyo (H. C.) -Nearly black, finest dark red, in curved blooms. 75c.

Islam Patrol-Very dark, velvety scarlet, tipped and flushed with gold. One of the outstanding California Dahlias at all Eastern exhibitions held last season. Wonderful long stems; especially fine keeper for exhibition purposes. Winner of many prizes in California. $\$ 1.00$.

Jean Chazot-Decorative Cactus. One of the finest of the imported Dahlias. It is unsurpassed by any of the autumn tinted Dahlias as a cut flower. It is a free, upright grower; long, stiff, wiry stems hold the flowers well above the foliage in such manner as to display their full beauty. The color is a beautiful golden bronze, with just a faint suggestion of nasturtium red, which adds to its charm. $75 \mathrm{c}$.

Kalif-Its brilliant, pure scarlet color, strong, stout stems, and large, perfect formation make it one of our most useful hybrid cactus Dahlias. 75c.

La Favorita, H. C.-A splendid variety of brilliant orange. Good for cutting. 75c.

Lady Helen, H. C.-Giant flowers on strong, erect stems; deep cerise marked with cream. $\$ 1.00$.

Lucky Strike-A very large pure white hybrid cactus with exceptionally long stiff stems. The plant is a tall and vigorous grower. A very striking and attractive Dahlia, and is a fine exhibition flower. $\$ 1.00$.

Marian Broomall-This beautiful straight Cactus is an exquisite pure pink on the outer petals shading to white in the center, and has an extra large, beautiful flower, which is held erect with long, stiff stems-a very lovely Dahlia. Marian Broomall is one of our favorites, and always attracts much attention. Root $\$ 2.00$.

Mariposa-Always will be a favorite in our garden, and one of the "best sellers" all over the United States. Color a pure light pink with a touch of mauve. Good center. $\$ 1.00$. 


\section{HYBRID CACTUS DAHLIAS-Continued}

Miss Watsonville, H. C.-One of our new introductions. The color is most unusual and very attractive, being a bright fireman red, each petal being tipped with gold. Are beautifully twisted and curved. The blossoms are of good size and are admired by all who see them. A most desirable cut flower variety. Root $\$ 7.50$.

Magnificent-Ground color Oriental buff overlaid with rosy salmon. Very free bloomer. 75c.

Mrs. Ethel F. T. Smith-Hybrid cactus of very large size. Broad petals of cream white, shading to lemon. Good stem. $75 \mathrm{c}$.

Nibelungenhort-Cactus. About one-fifth decorative type. Soft amber pink, shading to flesh pink. Extremely pretty, and a good cut flower, either for the house or for exhibition. Root, each $75 \mathrm{c}$.

Nichu (Boston) H. C.-Very large incurved sulphur yellow with a perfect closed center. Abundant bloomer on strong stems, and one of the best in color. Root $75 \mathrm{c}$.

Regent-Large American cactus of clear mauve pink. Incurved formation of flower is very pleasing. Free bloomer. $75 \mathrm{c}$

Rollo Boy-Amber shading to old gold. Splendid grower and a profuse bloomer. You will like it, and find it worth the price. Root $75 \mathrm{c}$.

Santa Anna-Salmon rose suffused with gold. The flowers are held well above the dark green foliage on good stems. $\$ 2.00$.

Silverado (Seal) H. C.-One of the largest Dahlias ever introduced. A white, gradually shading to a faint lavendar center. Strong grower, producing blooms on stout stems of good length. One of the best sellers. Root $\$ 1.00$.

Thelma Jorgensen-A stunning big blossom of an attractive mixture of colors, calvary gold and dark orange. Some flowers on the bush are tipped white. Blooms freely on good stems. 75c.

Trentonian-A wonderful blending of old gold, amber and copper bronze, the whole forming a flower of marvelous beauty. $75 \mathrm{c}$.

Yosemite-Is a true type of hybrid cactus. Very large flowers, amaranth pink in color, grown on very long, strong stems. One of the most artistic flowers in the garden and a prolific bloomer. $\$ 5.00$. 


\section{Peony Dahlias}

A Little Bit o' Heaven-Light lavender with a slight suggestion of rose. A large flowering variety of merit. One of the finest of lavender-toned Dahlias. $\$ 1.00$.

Chocolate Soldier-Cactus-peony. It is of an entirely new type of Dahlia. The color is a new shade, rich velvety chocolate maroon, sometimes with a tinge of purple. The diameter of the flower will measure from 7 to 9 inches, with splendid long stems. When not debudded, every bud will develop a good, perfect flower. This variety is one of the most admired in our garden and is really a rather late-blooming Dahlia. Roots, each 75c.

Del Monte Sunshine-This plant is robust and upright in growth, throwing many beautiful blossoms at one time, on good long stems. The color is most unusual and attractive, being a bright fireman red, suffused and tipped with gold. Roots, each $\$ 1.00$.

Elizabeth Weitz-Peony. Crimson to cherry red, intermingled with paper white throughout the blossom, some few blossoms coming without the white. Splendid stems. One of the best new Dahlias. Roots, each 75c.

El Pajaro-Comes decorative form early in the season, but a little late in the season it is peony formation. The petals are extremely full and twirl and twist in a most artistic manner. Color pink, slightly suffused with yellow, rose pink outlining the outer edges and throughout the center of the petals. 75c.

Gorgeous-Very large flower of yellow, shading to bright scarlet. Held high on exceedingly long, stiff stems. A prize winner. $\$ 1.00$.

Grizzly-Maroon red, shading to deepest cherry. A very large and splendid California Dahlia. A robust grower. Roots, each $75 \mathrm{c}$.

Hall Caine-Color of orange red; very strong stem, and also a fine flower. $50 \mathrm{c}$

The Billionaire-Enormous flowers of a beautiful deep shade of gold. Pendant stem. 75c.

The Oriole-Fine big flower of a beautiful combination of burnt orange, red and yellow. Some blossoms tipped white. Free bloomer, on long, stiff stems. $75 \mathrm{c}$. 


\section{PEONY DAHLIAS-Continued}

The Screamer-A large-size flower with two to four rows of petals. Extra long, strong stems. The color is violet purple, suffused mauve. It is an exceptionally attractive flower. Roots, each $75 \mathrm{c}$.

Velvetta (Hibbard 1931) - The coloring of this beautiful Dahlia is difficult to describe; dark velvety maroon at the center, graduating to a Fuchsia. The large fine blossoms of great substance are held high above strong medium, tall bushes on extra long stiff stems; is one of the finest cut flowers. It was much admired in our garden for its unusually beautiful coloring. $\$ 7.50$.

Vivandiere-An immense deep peony of cerise carmine, shading lighter at the tips of the petals. The flower has a peculiar velvety texture. The stems of this early bloomer are excellent. Root 75c.

\section{Show Dahlias}

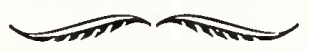

Bessie Boston-A large, deep cardinal red on strong stems. The petals are divided at tips. $50 \mathrm{c}$.

Cloth of Gold-Golden yellow, shading to brick red; very fine bloomer. 35c.

Glorie de Verdun-Decorative-show. Perhaps the brightest Dahlia in our whole collection. Crimson to bright vermillion. Almost a flaming ball. An importation which is greatly admired. Roots, each 75c.

Gloria de Lyon-The best white show. 50c.

Golden Opportunity-Buttercup yellow, orange to center. One of the best. $75 \mathrm{c}$.

Purple Queen-A perfect flower of purple. 50c.

\section{Collarette Dahlias}

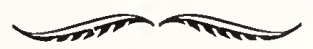

Cream Cup-White collarettes are very unusual. This is white with a white collar, and very popular. 35c.

Frogmore-Yellow, tipped red with yellow collar. 35c.

Silver Medal-Color is crimson maroon with each petal distinctly outlined in white, with a white collar in contrast. $50 \mathrm{c}$. 


\section{Pompon Dahlias}

\section{ALL POMPON DAHLIAS 3 FOR $\$ 1.00$}

Aimee-Tiny bronze flowers on long, erect stems.

Alice Irene-Creamy lemon.

Amber Queen-Deep amber.

Anne Doncaster-Yellow base, suffused pearly pink.

Achilles-Delicate lavender, tinted lilac.

Arthur Kerley-Deep, rich, cherry red.

Betty-One of the brightest. Crimson scarlet.

Bronze Beauty-Apricot, suffused bronze.

Clara Harsh-Yellow tipped crimson.

Darkeye-Lavender center and tips.

Fashion-A brilliant orange.

Girlie--Pure lilac, very popular.

Gretchen Heine-Creamy white, edged pink.

Gruss Am Wein-Crushed strawberry.

Glow-Beautiful shade of old rose.

Harry Snook-White, delicately shaded with pale pink.

Ideal-Clear yellow.

Joe Fette-Small, white, free bloomer.

Johnnie-Dark red, very tiny and of perfect form.

Little Bee's Wing-Red, shading to yellow.

Little Julia-Brightest orange vermillion.

Leda Beeler-Deep lilac, small and fine form.

Mary Munns-Fuchsia, dark orchid sheen, long stems.

Mike-Burnt orange, shading lighter at outer edge.

Pee Wee-Soft yellow center, shading to brown.

Prince Charming-White tipped rose.

Pure Love-Deep lavender.

Rosa Wilmoth-A fine rose pink, on ideal stems.

San Toy-White, tinted carmine rose.

Sunbeam-Crimson scarlet.

Sunset-Orange.

Tommy Keith-Variegated cherry red and white.

Tom Thumb-Very tiny bright red, smallest pompon.

Torres-Deep orange red and light orange.

Yellow Gem-Creamy yellow, small and fine form. 


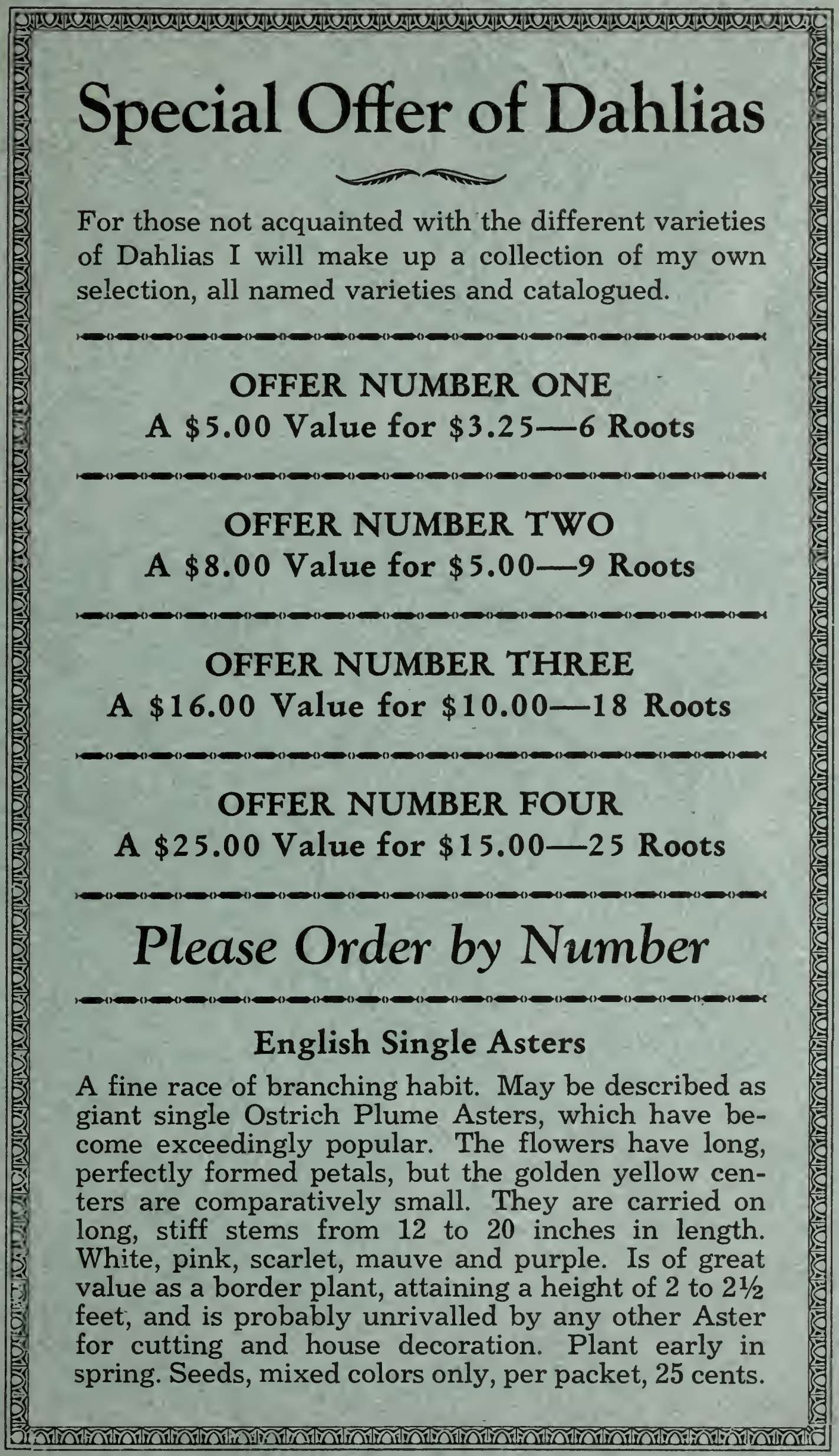




\section{Member \\ THE DAHLIA SOCIETY OF CALIFORNIA}

Watscnuille Press 225 Van Ness Ave. 